\title{
The Competency Requirements for Quantity Surveyors: Enhancing Continuous Professional Development
}

\author{
M.W. Mohd Shafiei and I. Said \\ School of Housing, Building and Planning, Universiti Sains Malaysia, \\ 11800 Minden, Pulau Pinang, Malaysia \\ Email: wira@usm.my
}

\begin{abstract}
Quantity surveyors are construction economists who fulfill varied and comprehensive duties to support cost-effective construction and property development projects. The core competencies of quantity surveyors include determining project budgets, measuring project quantities, preparing contract documentation (such as Bills of Quantities and Cost Control Documents), administering contracts, and preparing final accounts. Despite being recognised as a professional discipline distinct from architecture and civil engineering since 1836, quantity surveyors are not immune to the threats and changes in their operating environment. Some parties in the construction industry have been critical about the quality of works and services provided by quantity surveyors. Some even question the importance of appointing quantity surveyors as project consultants. Because of these challenges, the profession needs to regroup and take stock of the whole situation so that they will not become extinct in the future. All parties who have vested interest in the development of the profession, be it the students, educators, registered as well as unregistered quantity surveyors must find an answer to arguably, the declining roles of quantity surveyors and the lack of recognition they receive in construction projects. Two pertinent issues that had been discussed by these people are: the competency level of practicing quantity surveyors who offer their services to the clients; and the amalgamation of a set of competency standards into professional quantity surveyors' training, formally named as 'continuous professional development' (CPD) by the profession. Competence, in any sphere of work, can be a difficult concept to pin down. It is particularly difficult when it relates to professional occupations where roles can be complex and the knowledge and skills involved many and varied. Recognising the importance of professional competence, a research looking into issues relating to quantity surveyors' competency had been conducted by the Universiti Sains Malaysia, Malaysia. The on-going research looks into the national competency standards, industry needs, job profile charts, and delivery of learning materials to quantity surveying students. The research findings reveal that, quantity surveying educators and practices alike, are still deeply entrenched in the 'traditional' core competencies rather than the newer and more novel services and skills. The research respondents however, recognised that university educators in the field of quantity surveying need to develop a comprehensive course syllabuses that cover the whole spectrum of knowledge/cognitive, functional, and behavioural competencies in order to produce competent and employable quantity surveyors for the nation. Lastly, the respondents are generally supportive of
\end{abstract}


having a Malaysian version of competency standards for the quantity surveyors. They are also confident that these standards can become the lynchpin for a comprehensive continuous professional development programme.

Keywords: Competency, Continuous Professional Development, Occupational Skills, Quantity Surveying, Training

\section{Introduction}

Quantity surveyors are key professionals in the construction industry and their clients include developers, government bodies and agencies, building proprietors, architects and contractors. They can be involved in cost planning, cost management, project procurement, contract administration, feasibility studies and asset financial management.

The wide array of quantity surveyors' responsibilities means that they have to be educated, trained, and highly skilled in diverse subjects. Lenard (2000) argued that the changing nature of the construction and development industry such as the adoption of innovative technological processes and development, the emergence of highly focused professionals and the full range of advanced technologies will necessitate a much stronger emphasis on job competencies than ever before.

However, competence, in any sphere of work, can be a difficult concept to pin down. It is particularly difficult when it relates to professional occupations where roles can be complex, and the knowledge and skills involved many and varied (Cheetham and Chivers 1996).

In order to arrive at a suggested model of competencies and skills for quantity surveyors, it is important to elaborate and discuss the job scopes and varying roles of quantity surveyors, be it in professional firms, contracting organisations, and construction client bodies. This paper will firstly, describe the profession of quantity surveyors, then followed by discussion on quantity surveyors' job competencies, deliberation on the research findings and lastly, description on the suggested model of competencies for quantity surveyors.

\section{Quantity Surveying Profession}

The origins of quantity surveyors can be traced back to the ancient Egyptian civilisation who used dedicated personnel to carry out estimates and costing for their magnificent structures and buildings. It developed into an occupation during the 17th century restoration of London after the Great Fire. In 1836 the profession entered its new age when the new Houses of Parliament of Great Britain, designed by Sir Charles Barry, became the first major public contract to be fully measured and tendered using detailed bills of quantities for financial accountability (RICS 2005).

A quantity surveyor is a professional in the construction industry who has the ability to analyse both cost components and practical physical construction works of a project in a successful way so as to be able to apply the results of his analysis in solving problems peculiar to each project (Badu and Amoah 2004). 
In general, the principal services that could be offered by any quantity surveying firm are (John Austen Associates 2004):

- Preliminary cost advice and feasibility estimates.

- Cost planning.

- Advising on contractual methods.

- Advising on selection of other consultants.

- Advising on contractor selection.

- Preparing tender documents.

- Obtaining or negotiating tenders.

- Reporting on tenders received or package deal/design and build offers.

- Evaluating construction work.

- Preparing and agreeing accounts for/with contractors.

- Preparing expenditure statements for tax accounting purposes.

- Periodic financial reporting

- Technical auditing.

- Assessing replacement value for insurance.

- Project management related services.

- Giving expert evidence in arbitrations, adjudications and legal disputes.

- Preparing/defending against construction contract claims.

From being a trade-based vocation, quantity surveying had developed into a full-fledged profession widely accepted in the construction industry. The quantity surveyor, in its present day construction industry, uses his ability to analyse cost components of a construction project in a scientific way and applies the results of his analysis to a variety of financial and economic problems confronting the developer and the designer. Badu and Amoah (2004) held that these changing roles had been redefined by the educational system received by the quantity surveyors.

\section{Different Roles of Quantity Surveyors}

There are several options in the quantity surveying field. A qualified quantity surveyor can usually gain employment in quantity surveying firms, construction companies, or property developers. Some large public or private organisations that deal with a significant amount of building or construction procurement as part of their activities normally employ quantity surveyors among other construction professionals to become their project managers.

Quantity surveyors working in consultant firms are retained by the construction clients to ensure that what is eventually built is what the clients want or could afford (National Commercial Services UK 2004). The responsibilities of the client's quantity surveyor include the preparation of Bills of Quantities and the giving of advice on what a project would cost. He also does cost planning during the design stage of a project, examines tenders, prices quantities and reports his findings. He also negotiates rates with contractors on negotiated contracts, valuing work in. The distinctive skill of a quantity surveyor lies in his ability to analyse a project using the above knowledge and apply it to 
the following areas like progress payment and making recommendations as to payments to be made to the contractor including advising on the financial aspects of variations (Badu and Amoah 2004).

The contractor's quantity surveyor on the other hand engages himself in matters relating to costs and estimates from the perspective of 'entrepreneurial' contractor, and agrees on measurements with the client's contractor for any specific project. The principle role of the quantity surveyor here is to look after the financial interests of the contractor. He will calculate and record the financial value of the work carried out and ensures that the contractor is paid properly and on time. During the currency of the contract, he will be involved in measurements on site and from drawings in order to establish the true value of work done in the interim period (National Commercial Services UK 2004). He also collects information about cost of various operations or method of construction from which the contractor can prepare future estimates. He might also be tasked to prepare the project report and assist the contractor in his management scheduling plans (Badu and Amoah 2004).

\section{A Discussion on Competency}

The issue of workers' competencies had been discussed by industrialists, management practitioners and academics alike since the 1960's. Concerns had been raised by them about the difficulty in transferring core competencies to the next generation of employees, and the resultant effect of this transfer to the firm's ability to sustain its competitive advantage across diverse environments (Hamel and Prahalad 1990, Siddiqi 2000). However, the thinking on competencies and corporate strategy remained dormant during the 1970s and early 1980s, the reason being that management practitioners and academics paid more attention to other approaches of strategy (Anjana-Kak 2002). In the late 1990s the idea of competence had gained greater credence and widely used by industries. Rankin (2000) reported that a significant number of companies in the UK are using competencies to improve individual and corporate performance. Baker et al. (1997) observed that companies were starting to look into workers' competencies when they realised that providing a framework which brings greater clarity to the idea of competence in business in general, and operations and technology management in particular, would bring competitive advantage to their organisations.

What is competence? In this paper, the term is not to be likened with the concept of "core competence' as developed by the likes of Hamel and Prahalad (1990), Stalk et al. (1992), and Tampoe (1994). For them, core competence refers to an integrated set of core technologies and core skills that provide an organisation with its competitive advantage. It is more organisationally driven rather than individually focused. But Boyatzis (1982), Schroder (1989) and Burgoyne (1993) are more interested in the 'individual' aspect of competence. The concept is widely used in human resource management. Individual competence refers to the set of skills that an individual must possess in order to be capable of satisfactorily performing a specified job.

Holmes and Joyce (1993) defined competence as action, behaviour or outcome which a person should be able to demonstrate, or the ability to transfer skills and knowledge to 
new situations within an occupational area. Meyer and Semark (1996) have added two new dimensions into this definition i.e. personal attributes and value orientation. Roggema-van Heusden (2004) attempted to define competence from professional personnel point of view. They held that, competence is the ability to perform well in a professional situation that involves the accomplishment of a certain task or the dealing with a problem, in a manner that can be observed and be judged by others. That is to say: a competent professional is capable of applying the necessary expertise in confluence with effective behaviour.

\section{The Competency Model}

As the needs and expectations of construction clients have changed, particularly since the decade of the nineties, so have their expectations of professional services in the built environment. Whereas professional services have been engaged without hesitation in the past, questions about relevancy in terms of value added to the project are now being asked (Procter 1997). Because of the more discerning clients, the profession needs to regroup and take stock of the whole situation so that they will not become extinct in the future. Prokesch (1997) argued that knowledge base of the profession could be the key in unlocking the potential of the profession and meeting the changing client needs. $\mathrm{He}$ believed that, one way of updating and leveraging the profession's knowledge base is to ensure that the constituent skills, abilities and values of the profession are subjected to periodic auditing to highlight critically important competencies. The proficiency levels of practitioners in these competencies can then be assessed to identify areas of focus for relevant education and training for quantity surveyors.

In 1998, The Royal Institution for Chartered Surveyors (RICS) had put forward a model of competencies for quantity surveyors. The model, as shown in Table 1, was presented under three categories of basic, core and optional competencies.

Table: 1 Competencies Required of Quantity Surveyors for Professional Competency (RICS)

\begin{tabular}{lll}
\hline Basic Competencies & Core Competencies & $\begin{array}{l}\text { Optional } \\
\text { Competencies }\end{array}$ \\
\hline $\begin{array}{l}\text { Personal \& } \\
\text { interpersonal skills }\end{array}$ & $\begin{array}{l}\text { Construction contract } \\
\text { practice }\end{array}$ & $\begin{array}{l}\text { Arbitration \& other } \\
\text { dispute resolution } \\
\text { procedures } \\
\text { Development appraisal }\end{array}$ \\
$\begin{array}{l}\text { Construction } \\
\text { technology \& } \\
\text { environmental services }\end{array}$ & Fata, information and \\
$\begin{array}{l}\text { Economics of } \\
\text { construction }\end{array}$ & $\begin{array}{l}\text { Procurement and } \\
\text { Professional practice }\end{array}$ & Insolvency \\
$\begin{array}{l}\text { Law } \\
\text { Measurement management }\end{array}$ & & $\begin{array}{l}\text { Insurance } \\
\text { Project management }\end{array}$
\end{tabular}




\begin{tabular}{ll} 
Mapping & Property investment \\
funding & Research \\
methodologies \& \\
techniques \\
Valuation \\
Taxation allowances \& \\
grants \\
\hline
\end{tabular}

The Australian Institute of Quantity Surveyors (AIQS) also attempted to define and develop a model of competencies for the quantity surveyors (AIQS 1998). They had proposed 31 competency standards that need to be adhered to by the professional body in producing competent quantity surveyors. Apart from the competency standards, the Australian Institute of Quantity Surveyors also recommended the basic characteristics of abilities that lead to a competent quantity surveyor. These basic abilities in turn, form the platform from which a competent quantity surveyor can develop and are an integral part of the 31 units of competency standards. The basic abilities are:

- Quantification/measurement - the ability to quantify and enumerate.

- Analysis - the ability to observe, assess, identify problems and find innovative solutions.

- Appraisal/evaluation - the ability to assess value.

- Communication - the ability to impart knowledge, ideas and concepts through oral, written and visual means.

- Interpersonal skills - the ability to effectively work with others and to be part of a team.

- Leadership - the ability to lead and motivate.

- Self-development - the ability to set goals, display enthusiasm, self motivate and undertake research.

- Management - the ability to organise, monitor, control and plan the effective use of resources.

- Documentation - the ability to prepare written information in a format which clearly conveys meaning.

- Synthesis - the ability to combine fact or ideas into a complex whole.

- Computer literacy - the ability to understand and apply basic computer skills.

- Construction technology - the ability to understand basic construction technology.

- Construction law and regulation - the basic knowledge of national laws and regulations related to construction.

In 1999, The Pacific Association of Quantity Surveyors (PAQS) had analysed a full range of competencies required by a modern quantity surveyor. In principle they agreed to accept 10 competency standards for their quantity surveyors. Those are:

- Strategic planning.

- Budgetary process. 
- Cost estimating.

- Cost planning.

- Procurement advice.

- Documentation.

- Tendering process.

- Construction account management.

- Construction change management.

- Feasibility studies.

\section{Competency Standards for the Malaysian Quantity Surveys}

The quantity surveyor competency model developed by the AIQS, RICS, and PAQS had been used to formulate the theoretical framework for this study. The competency standards models developed by these three organisations model were perceived to be the most comprehensive ever developed to date. The research aim is to put forward a model of competencies for professional quantity surveyors in Malaysia. Literature search conducted in the earlier stage of the research revealed that a Malaysian model of competency standards for the quantity surveyors had not been developed before.

A sample of 50 quantity surveying firms registered with The Board of Quantity Surveyors, Malaysia was randomly selected for this study. Postal questionnaires were sent to these firms in January 2005. By the 20th of February 2005, 12 firms had returned completed questionnaires to the researcher. A small number of filled questionnaires received after the cut off date (20th February) was not analysed due to time limitation of the research. Hence, the effective research respondents are $12(\mathrm{~N}=12)$, a response rate of $24 \%$.

\section{Basic Characteristics, Abilities and Knowledge of a Competent Quantity Surveyor} The respondents were asked to give their opinion on a given list of characteristics, abilities, and knowledge of a competent quantity surveyor. The list, adapted from the Australian Institute of Quantity Surveyors' competency model contained 13 characteristics, abilities, and knowledge. The results are shown in Table 2 that is in the next page.

Overall, all the respondents were agreeable to the list of basic characteristics, abilities and knowledge of a competent quantity surveyor proposed to them. This is because, the lowest importance index reading is 81.67 (for 'computer and information technology literacy'). Hence, it could be deduced from the result that, the respondents are generally accepting the importance of all the items in the list provided to them. The respondents stated that, the most important characteristics, abilities and knowledge for quantity surveyors to possess are quantification/measurement, analysis, and interpersonal skills. Communication, documentation, and construction technology are also regarded as highly important for quantity surveyors to achieve an accepted level of competency. Other less important characteristics, abilities and knowledge to acquire are management, appraisal/evaluation, construction law and regulation, self-development, leadership, synthesis, and computer and information technology literacy. 
Table: 2 Basic Characteristics, Abilities and Knowledge of a Competent Quantity Surveyor

\begin{tabular}{|c|c|c|c|c|c|c|}
\hline \multirow{2}{*}{ Characteristic } & \multicolumn{5}{|c|}{ Respondent Scoring* (\%) } & \multirow[t]{2}{*}{$\begin{array}{l}\text { Imp. } \\
\text { Index }\end{array}$} \\
\hline & 1 & 2 & 3 & 4 & 5 & \\
\hline $\begin{array}{l}\text { Quantification / } \\
\text { Measurement }\end{array}$ & 0 & 0 & 0 & 25.00 & 75.00 & 95.00 \\
\hline Analysis & 0 & 0 & 0 & 25.00 & 75.00 & 95.00 \\
\hline Interpersonal skills & 0 & 0 & 11.11 & 58.33 & 41.67 & 95.00 \\
\hline Communication & 0 & 0 & 0 & 50.00 & 50.00 & 90.00 \\
\hline Documentation & 0 & 0 & 0 & 50.00 & 50.00 & 90.00 \\
\hline Construction technology & 0 & 0 & 0 & 50.00 & 50.00 & 90.00 \\
\hline Management & 0 & 0 & 0 & 58.33 & 41.67 & 88.33 \\
\hline Appraisal / Evaluation & 0 & 0 & 0 & 66.67 & 33.33 & 86.67 \\
\hline $\begin{array}{l}\text { Construction Law and } \\
\text { regulation }\end{array}$ & 0 & 0 & 0 & 66.67 & 33.33 & 86.67 \\
\hline Self-development & 0 & 0 & 11.11 & 66.67 & 25.00 & 85.00 \\
\hline Leadership & 0 & 0 & 0 & 75.00 & 25.00 & 85.00 \\
\hline Synthesis & 0 & 0 & 11.11 & 75.00 & 16.67 & 83.33 \\
\hline $\begin{array}{l}\text { Computer and } \\
\text { information technology } \\
\text { literacy }\end{array}$ & 0 & 0 & 8.33 & 75.00 & 16.67 & 81.67 \\
\hline
\end{tabular}

* 1- Not important, 2- Less imp., 3- Neutral, 4- Important, 5- Very imp.

Three pertinent points came out from this result. Firstly, the respondents widely accepted that interpersonal skills are one of the three most important abilities to acquire for any would-be competent quantity surveyors. This finding shows that apart from quantity surveying related knowledge, it is important for quantity surveyors to acquire the 'soft' skill such as interpersonal skills to help them carry out their work in a competent manner. Secondly, it is interesting to note that documentation did not come up top in the ranking of characteristics, abilities and knowledge importance. According to popular belief, the knowledge of documentation should be one of the most important aspects of quantity surveying work. Apparently, the respondents disagreed with such a belief and did not place documentation in a higher position of importance. Similarly, construction law and regulation - popularly perceived as one of the most important scopes of quantity surveyors did not make it to the most important or even highly important list of characteristics, abilities and knowledge for quantity surveyors. Thirdly, computer and information technology literacy was not ranked high enough by the respondents as important in the pursuit of quantity surveying competency. This is despite the nature of quantity surveyors work that relies heavily in cost estimates and quantitative-based activities. With the help of computers and advanced designer software, surely it would make their work much faster, accurate and error-free. 


\section{Competency Standards for Quantity Surveyors}

The study was based on the AIQS' model of competency standards for quantity surveyors. In all, there are 13 competency standards to be tested by the study (as shown in the preceding page). Early findings indicate that 'contract documentation', budgetary process' and 'tendering process' are consistently ranked higher than the other standards by the respondents. This warrants further scrutiny during the next round of data collection.

At the time of writing, the Board of Quantity Surveyors Malaysia and the Ministry of Higher Education Malaysia had just released their final draft of 'Criteria and Standards for Educational Programmes in the Field of Quantity Surveying' to be used by all public universities offering degrees in quantity surveying programmes. The criteria and standards are prepared as part of the Ministry of Higher Education Malaysia's ambition to assure the quality of higher education in the field of built environment. Other fields of studies within the built environment disciplines which have formulated their own respective criteria and standards are architecture, interior architecture, landscape architecture, land surveying, building surveying, urban and regional planning, valuation and real estate management, and construction.

The Board of Quantity Surveyors Malaysia agreed that, the general education goals for quantity surveying educators in Malaysia are to educate, train, and produce graduate quantity surveyors who are competent, creative and versatile, guided by high moral and ethical values for God and Mankind.

After completing the quantity surveying education programme, the graduates should possess knowledge, understanding, skills and competencies in:

1. Meta-competencies - versatile and adaptable, pro-active and positive thinking, able to communicate effectively, high self-esteem, highly creative and innovative with problem solving ability, able to work in team, high ethical and moral value and lifelong learning outlook.

2. Construction economics, cost and financial management - including project cost estimating and cost plans, preparing project budget and cash flows, administration of project cost and finance, carrying out feasibility and viability studies including collecting, preparing, analysing, and interpreting project cost and financial data and related information.

3. Management of construction project procurement and contract - inclusive of identifying, collecting, processing and interpreting data and information for the evaluation and selection of appropriate procurement system and contractual arrangement, preparing tender and contract documents, administration of tendering processes and managing the implementation of construction contract.

4. Measurement, quantification and documentation - inclusive of measuring and quantifying construction works for project costing, cost planning and control, preparation of bills of quantities, work programme, resources planning and control, valuation for interim payment, and preparation of project account. 
5. Construction technology and engineering - inclusive the use of construction technology and engineering, knowledge of materials, plant, machinery and manpower in quantity surveying functions, cost and financial management, and contract administration.

6. Information and communication technology - not only to utilise the latest ICT in carrying out the quantity surveying functions but also to design and/or develop esystems for quantity surveying work, processes and procedures.

7. Project management principles and practice - in providing quantity surveying services and the management of project cost, finance, procurement and contract.

8. International QS practice - inclusive of local and international construction and quantity surveying technology, work process and procedure and their changes and development.

The 8-points criteria and standards as proposed by the Board of Quantity Surveyors Malaysia are already in final draft stage. Barring major changes by the higher authority, it is expected that all local universities would adhere to these proposed competency framework in educating the future generations of quantity surveyors.

The joint efforts made by the Board of Quantity Surveyors and The Ministry of Higher Education to educate the quantity surveying students according to a set of competency standard can only be lauded. The next challenge to be fronted by the Boad of Quantity Surveyors Malaysia is to follow through the education and training standards for the practicing quantity surveyors. Devoid of competency standards-based education during their tertiary study days, these generations of quantity surveyors are in great needs of a comprehensive 'continuous professional development'. This programme should specifically train them on all the critical competency standards discussed in this paper earlier. Nearly all the research respondents $(\mathrm{N}=10)$ indicated their agreement towards using competence-based training and education approach in the professional development of post-university quantity surveyors. They accentuated their point by agreeing that, this approach should become the keystone in the Board of Quantity Surveyors' continuous professional development programme.

\section{Conclusion}

The study revealed that the quantity surveying fraternity is serious in establishing their own competency standards to improve and maintain the services provided by professional quantity surveyors. Various professional quantity surveying organisations such as RICS, AIQS, and PAQS had already established the competency standards for their own use. Whatever model they follow, the Malaysian quantity surveyors were found to be very receptive towards the idea of adhering to these prescribed standards in producing competent quantity surveyors. The next challenge in the profession would be to improve the competency standards models a step further, and to extend their use to a larger number of quantity surveying practices. In view of the competency framework proposed by the Board of Quantity Surveyors Malaysia in August 2005, more research works need to be done to see the benefits of the prescribed competency standards coming from the various professional quantity surveying bodies. 


\section{References}

Anjana-Kak, S. (2002), Sustainable Competitive Advantage with Core Competence: A Review, Global Journal of Flexible Systems Management, Australian Institute of Quantity.

Badu, E. and Amoah, P. (2004), Quantity Surveying Education in Ghana, The Hgana Engineer.

Baker, J.C., Mapes, J., New, C.C. and Szwejczewski, M. (1997), A Hierarchical Model of Business Competence, Integrated Manufacturing Systems, Bradford.

Boyatzis, R.E. (1982) The Competent Manager: A Model for Effective Performance, Wiley, New York.

Cheetham, G. and Chivers, G. (1996), Towards a Holistic Model of Professional Competence, Journal of European Industrial Training.

Hamel, G. and Prahalad, C. (1990), The Core Competence of the Corporation, Harvard Business Review.

Holmes, L. and Joyce, P. (1993), Rescuing the Useful Concept of Managerial Competence: From Outcomes Back to Process, Personnel Review, Vol. 22 No 6.

John Austen Associates (2004), http://www.john-austen.co.uk [Accessed on the $3^{\text {rd }}$ of September 2006].

Lenard, D. (2000), Future Challenges in Cost Engineering: Creating Cultural Change Through the Development of Core Competencies, AACE International Transactions.

Meyer, T. and Semark, P. (1996), A Framework for the Use of Competencies for Achieving Competitive Advantage, South African Journal of. Business Management, Vol 27 No 4.

National Commercial Services UK (2004), http://www.ncsuk.com [Accessed on the $5^{\text {th }}$ of October 2006].

Procter, C. (1997), Satisfaction and Service Quality in the Quantity Surveying Profession, University of Cape Town.

Prokesch, S. (1997), Unleashing the Power of Learning: An Interview with British Petroleum's Jown Browne, Harvard Business Review.

Rankin, N. (2000), Annual Survey of Competency Frameworks, Competency and Emotional Intelligence, IRS.

RICS (2005), http://www.rics.org [Accessed on the $5^{\text {th }}$ of October 2006].

Roggema-van Heusden, M. (2004), The Challenge of Developing A CompetenceOriented Curriculum: An Integrative Framework, Library Review, Vol 53 No 2.

Royal Institution of Chartered Surveyors (1998), The APC Requirements and Competencies, Royal Institution of Chartered Surveyors, London.

Schroder (1989), Managerial Competence, Kendall-Hunt, LA.

Shahid Siddiqi (2000), Customising Core Competencies: The Regional Challenge, Indiana.

The Australian Institute of Quantity Surveyors (1998), National Competency Standards for Quantity Surveyors, AIQS, Australia. 